\title{
Based on the Puritan Concept and Ethical Spirit: the Preliminary Formation of African American Political Culture
}

\author{
Shu Qi ${ }^{1}$ \\ ${ }^{1}$ School of Political Science and Public Administration, China University of Political Science and Law, Beijing, China \\ Correspondence: Shu Qi, Doctoral Candidate, School of Political Science and Public Administration, China University of \\ Political Science and Law, Beijing, China.
}

Received: January 31, 2019

Accepted: February 15, 2019

Available online: February 20, 2019

doi:10.11114/ijsss.v7i2.4015

URL: https://doi.org/10.11114/ijsss.v7i2.4015

\begin{abstract}
Puritan ideas and ethics are not only the cradle of the mainstream political culture in America, but also the ideological source of the African American political culture. However, what was the significance of puritanism for the emergence of early political ideas among black American? To answer the question, it is necessary to delve into the meaning of puritanism to the political culture of the black American. This paper will elaborate on the crucial role of puritanism in the formation of black political culture in America from three aspects, that is, establishing a close relationship between puritanism and African American political culture. In order to understand it profoundly, three relationships will be established and explained. Respectively, the first one is to establish the relationship between Puritan idea especially the concept of equality and African American political idea; the second one is to establish the relationship between Puritan life and African American political elites; the third one is to establish the relationship between Puritan ethical spirits and moral norms and African American self-consciousness. More specifically, First of all, the germination of the early political ideas of African American was based on Puritan ideas; Secondly, Puritan life was the cradle of the growth of black political elites; Finally, the Puritan ethical spirit, such as diligence and frugality, diligence and hard work, tidiness and cleanliness, decent behavior and other basic behavioral norms, had a deep influence on the cultivation of the moral behavior norms and the formation of self-consciousness of African American.
\end{abstract}

Keywords: African American, political culture, Puritan, puritanism, equality, liberty

\section{Introduction}

\subsection{Introduce the problem}

From the perspective of political development, the politics of black American has evolved according to a political logic which is from sensibility to reason, from mobs to elites, from closure to integration, from freedom to equality, from slaves to citizens, and from ethnic groups to the state. In the changing historical process, a kind of political subculture, which is both dependent on and independent of the mainstream American political culture, has been gradually formed, namely the black American political culture. It was no exaggeration to say that puritanism attached its soul to the North American political cultural tradition and the process of the construction of the American political system.

Puritan ideas and ethics are not only the cradle of the mainstream political culture in the United States, but also the ideological source of the African American political culture. During the colonial period, the separatists who supported secession from the state religion in 1620 took the Mayflower, far away from the political blockade and religious persecution in Britain, and became the first group of Puritan newcomers to the new continent of the North America. And then, New England became a holy land for Puritans to carry out church activities, political activities and ideas. Puritanism developed rapidly, and the Puritans gained an advantage not only in number but also in geographical scope; and under the influence of ideas and ethics of puritanism, the secular order was gradually established within the logical framework of modern society. Therefore, puritanism had a profound impact on the political tradition of the North America, and it laid a deep ideological foundation for the formation of American Anglo-Saxon political culture. Tocqueville put it bluntly: "we must never forget that it was religion that made Anglo-American society possible" (trans., 2011, p. 521).

According to Vernon Louis Parrington, the Puritan heritage of 1620-1660 was the cradle of American liberalism (trans., 2002, p. 8). He believed that "the whole set of ideas which Puritan immigrants brought to America and characterized the 
New England spirit could be summed up in one sentence, that of Carolina liberalism" (trans., 2002, p. 8). Actually, Puritan theology had infiltrated into the democratic political thought and system in the new continent of the North America. Even though some theories of puritanism were quite different from the basic value orientation of liberalism, the cultivation of American liberalism by puritanism is beyond doubt. Qian (2006) said "Puritanism at the same time developed the opposite ideology, making them not against liberalism but to promote its development" (p. 9). In a word, the North American colonies were religious shrines for believers to purify their faith and get close to God; it was also a governmental entity with rational new people reforming the old system and getting infinitely close to the rights. Thus, Kahn (2015) described the North American colonies as "both a religious and a financial enterprise" (trans., p. 91). It was no exaggeration to say that puritanism attached its soul to the North American political cultural tradition and the process of the construction of the American political system. In other words, North American colonial spirit was the transmission of Puritan spirit; North American colonial culture was the inheritance of Puritan culture; North American colonial politics was an inevitable product of Puritan ideas.

There is no doubt that Puritan thought and ethical spirit played an important role in the construction of the mainstream political culture of the white American. What, however, was the significance of puritanism for the emergence of early political ideas among black American? What parts of the constitutional thinking of early black leaders in the United States were influenced by puritanism? Or, how do we understand the relationship between puritanism and African American political culture? What role did puritanism play in the intermingling of cultures? How do mainstream culture and non-mainstream culture gradually integrate, and how do they maintain their relative independence from each other in the United States characterized by multiculturalism? Is puritanism the conceptual basis for cultural integration? To answer these questions, it is necessary to delve into the meaning of puritanism to the political culture of the black American.

This paper will elaborate on the crucial role of puritanism in the formation of black political culture in America from three aspects. First of all, the germination of the early political ideas of African American was based on Puritan ideas. This is mainly reflected in two aspects: on the one hand, the germination of the African American concept of equality, with the spiritual equality in puritanism as the theoretical guide, and with the spread of European liberal political values and the full integration of the actual situation of the African American political revolution, gradually completed the transformation and development from religious belief to the concept of realistic politics; On the other hand, the early African American concept of equality was attached with a holy veil of religious belief and worship. It established a close relationship between faith, morality and politics, like the relationship between source and flow, root and stem, and repeatedly took moral and ethical order as the basis to fully demonstrate the natural state of realistic political order. Secondly, from the perspective of the cultivation of political elites, Puritan life was the cradle of the growth of black political elites in America. In religious affairs, the African American political elite not only acquired the necessary skills such as speech and eloquence, political logic and expression. Moreover, it was easier to gain respect, honor and worship in the black community, thus becoming an influential spokesman of the black community. Finally, the Puritan ethical spirit, such as diligence and frugality, diligence and hard work, tidiness and cleanliness, decent behavior and other basic behavioral norms, had a deep influence on the cultivation of the moral behavior norms and the formation of self-consciousness of African American.

\subsection{The Concept of Political Culture}

When it comes to the political culture of African American, it is inevitable to make the concept of political culture involved. Political culture was first used in 1956 by the American political scholar Gabriel A. Almond. The following year, Almond and Sidney Verba (2008) examined the internal logic between the democratic systems and political cultures of the five democracies, and published The Citizen Culture: Political Attitudes and Democracy in Five Nations in 1963. In the Comparative Politics Today, Almond and Powell (1984) put forward that "political culture is a set of political attitudes, beliefs, and emotions popular among a nation in a specific period" (p. 29). In The Blackwell Encyclopedia of Political Science, political culture was described as "relating to the concepts of culture, spirit, emotion, or values that determine the political behavior of a nation or group" (Miller D. \& Vernon B., trans., 1992, p. 550). Generally speaking, in a political community, the formation of political culture generally depends on the geographical environment, the feelings, beliefs, political, economic, cultural and other conditions of the members within the community. Political culture has a long-term influence on community members' political consciousness, political emotion, political attitude, political psychology and political behavior.

\subsection{Literature Review}

As a very important part of American political ecology, African American politics has been paid much attention by western academic circles for a long time. The study of African American political culture in the academic world usually flashes in the results of the study of black history. Philip Foner (1975) in the History of Black America examines the 
black lives in Africa, the rise of the cotton empire, the compromise of 1850, and the struggle for black rights during the civil war. In addition, Foner also made a tentative discussion on the origin of African American political culture. Two volumes of In Their Own Words: A History of the American Negro 1865-1916 worked by Meltzer (1965), and Eyewitness: The Negro in American History worked by Katz (1968) are two extremely valuable collections of the black self-narratives. The anthology not only fully collects the experience of the African American political elite, but also extensively collects the political expression of the African American people. Therefore, this collection provides invaluable historical data for the study of African American political culture. Black Leader of the 19th Century worked by Litwack and Meier (1923) is a two-volume book pointing out the political ideas of African American political leaders in different historical periods. It is a worthwhile book for the interpretation of African American political thoughts.

Domestic research in China about African American politics started late. It was not until the 1950s and 1960s that African American political issues gradually came into the research field of domestic scholars. In the early stage, the domestic academic research on the African American community mainly focused on the racial slavery, the basic situation of the black struggle during important historical periods, and the political thoughts of prominent black political leaders. Among them, the most representative work was A Brief History of the African American Movement compiled by the Department of American history of Nankai University (1977). Also worth mentioning was a study of African American Leaders and Their Political Thoughts by professor Wang Enming from Shanghai International Studies University (2006). This book basically included the political thoughts of the important African American political leaders in the history of the African American struggle, such as Frederick Douglass, Booker T. Washington, W.E.B. Dubois and other significant political thoughts. Besides, associate professor Chen Zhijie was devoted to the study of African American history, and he wrote a meaningful academic works, that was Adaption and Antagonization: The Making of Black Culture under American Slavery (2010). This work deeply concentrated on the black slaves who suffered from the persecution of racial slavery and their production and living conditions, and comprehensively depicted their material living conditions, farming system, master-slave relationship, and problems of faith, organization mode and recreational activities. In general, the domestic academic circle has not yet formed a scale of research on the political culture of the black American.

Therefore, taking political culture as the research perspective and black American political culture as the research content can not only provide new ideas for American studies; Moreover, it offers partial insights into the whole, leading to a more comprehensive and profound understanding of contemporary American political issues.

\section{The Evolution of the Early Political Thoughts of African American Influenced by Puritanism}

It was the thought of equality in puritanism that played a crucial role in the germination of the early idea of equality and the initial formation of the thought of freedom and liberation of the African American. Actually, during the colonial period, the germination of the concept of African American equality was guided by the equality in puritanism. With the spread of European liberal political values and the full integration of the actual situation of the African American political revolution, the concept of African American equality gradually completed the transformation from religious belief to the concept of realpolitik. Actually, based on puritanism, especially the impact of the Puritan concept of equality, African American early political thoughts were established gradually. It will be discussed deeply in two important parts, that is, the first one is about the contents and impacts of African American early concept of equality, and the other one is about the primary characteristics and the evolutional logic of the early political view of African American.

\subsection{The Puritan Concept of Equality and the Preliminary Establishment of the Early Concepts of Equality and Freedom of African American}

During the colonial period, the theory of equality in puritanism was widely and deeply spread in the colonies, which laid the ideological foundation for the formation of the early ideas of equality and freedom of the African American. At the same time, influenced by the concept of Puritan equality, African American not only found a set of powerful weapons to attack the racial slavery, but also gradually formed the original framework of political thought in the enrichment of the concept of equality. Specifically, due to the existence of racial conflicts, education level, cultural level, social contradictions and other problems, most of the black slaves understanding of freedom and equality basically originated from the spread of the Gospel. Puritanism's interpretation of equality was based on the evilness of human nature, the choice of God and the difference of nature; and it took opposing absolute equality, advocating differential equality, and maintaining the traditional system as the central idea; but it was no denying that everyone was equal before God. Clearly, the Puritan definition of equality was more reflected in the ethical field and spiritual level. For most of the black people in the early time, they did not expect to be able to common share the governance with the white people in the mainstream society immediately. However, what they most urgent to do was to break away from the 
cages and shackles, so that life could be saved and the race could be continued. Early blacks saw the spiritual equality promoted by Puritan as powerful evidence to judge all kinds of crime committed by white people against black people. The reason why this evidence was so compelling, why it was used by black people to crush white people's hypocrisy, was because it came from the mouth of God, which represented the justice.

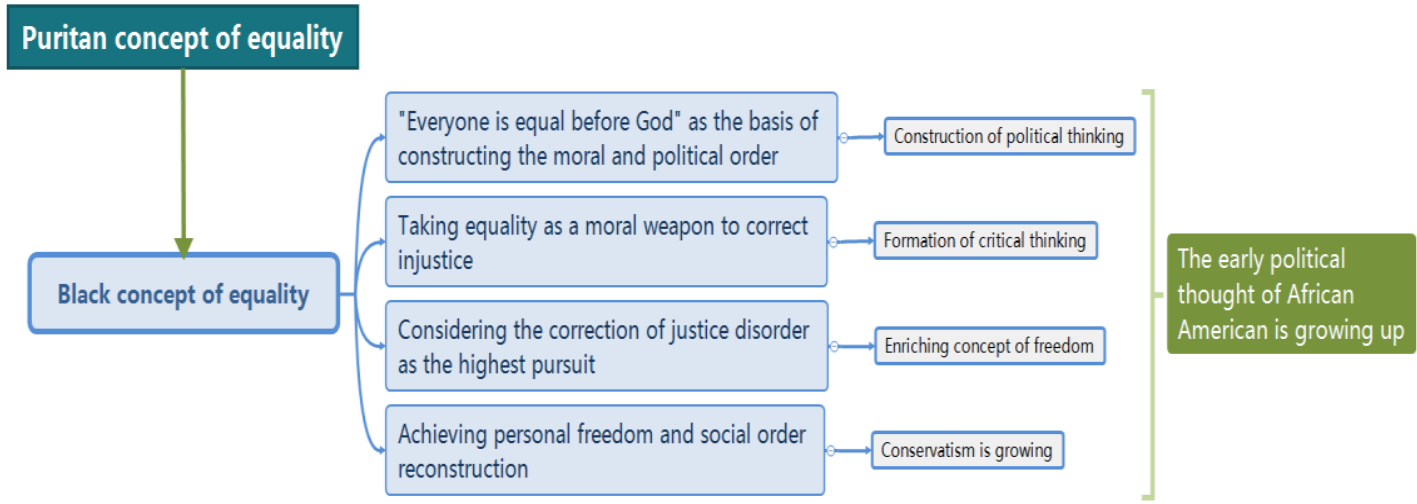

Figure 1. Contents and impacts of African American early concept of equality

As shown in the figure, from the perspective of practical significance, the equality pursued by African American mainly includes the following four aspects: 1) the equality pursued by black American started from the logic of "everyone is equal before God", regarded the Puritan concept, especially the concept of equality, as the fundamental basis of constructing the moral order and political order in the modern society, and saw those thoughts, behaviors and systems that violated the Puritan ethical order as justice disorder; 2) taking equality as a moral weapon, moral criticism and system improvement were carried out on the justice disorder in the white mainstream society; 3) taking anti-racial discrimination and oppression, as well as the correction of justice disorder as the highest pursuit; 4) achieving personal freedom, the long-cherished wish of social order reconstruction. In a word, the initial concept of equality for African American started from the spirit of puritanism, took freedom as the belonging, and walked out a road of national liberation.

More importantly, the establishment of the concept of equality for black people indicates the gradual improvement of their political ability, which is mainly reflected in four aspects: 1) the fact that black American uses the Creed of "everyone is equal before God" as a sort of theory to bashing the political disorder, just precisely highlights that they are out of the violent bloody struggle, and turn to build theoretical foundation for their revolution by use of Puritan theory, which means that it is the first step to systematically construct their own political thinking based on the concept of equality; 2) using equality as a weapon to criticize the disorder of justice in the real order shows that African American have learned to apply theory to practice, which proves that the critical thinking of African American is gradually maturing; 3 ) in the process of opposing racial discrimination and oppression and yearning for freedom and liberation, American blacks have gradually constructed and enriched the concept of freedom; 4) the long-cherished desire of black American for the reconstruction of social order also contains the seed of their conservatism, which grows gradually in DuBois's theory and finally turns blacks into a special group with double souls.

\subsection{The Primary Characteristics and the Evolutional Logic of the Early Political View of African American}

Obviously, the main characteristic of African American early concept of equality was that it was attached with a holy veil of religious belief and worship; and then, it constructed a close relationship between faith, morality and politics which was just like the relationship between the source and flow, the root and stem, and it repeatedly took moral and ethical order as important evidence to fully demonstrate what the natural state of realistic political order should be. It seemed that in African American's mind, the political legitimacy of the realistic society was stemmed from the faith to Puritan as well as the worship to the order created by God. Once the moral system and political order were broken into a big mass of injustice, punishments would come without doubt, and black people should unite themselves together in order to be against the situation of justice disorder. From this point of view, it was not hard to find there was no reason for black American to not fight for freedom and equality appointed naturally by God. More specifically, by the late 1700s, many black people salved and even freed mutually believed that under the circumstances of sharing the same love of God, sharing the identical rights of liberty and equality was beyond reproach. For example, in February 1774, the Massachusetts Investigative Press published a petition of African American called "Sons of Africa", which stated 
clearly that the black American and the white people were of the same heavenly father who according to the law of nature, had distributed all he had created to all people to fully enjoy; but, under the circumstances, the situation in which one group of people was enslaved by another brutally could not be accepted (Foner, 1975, p. 299). It could be seen that according to the logic of early African American, God made all things and natural law, and the law in human society must follow natural law. To follow the law of nature was tantamount the will of God. In addition, all people were sons of God and were equal before God.

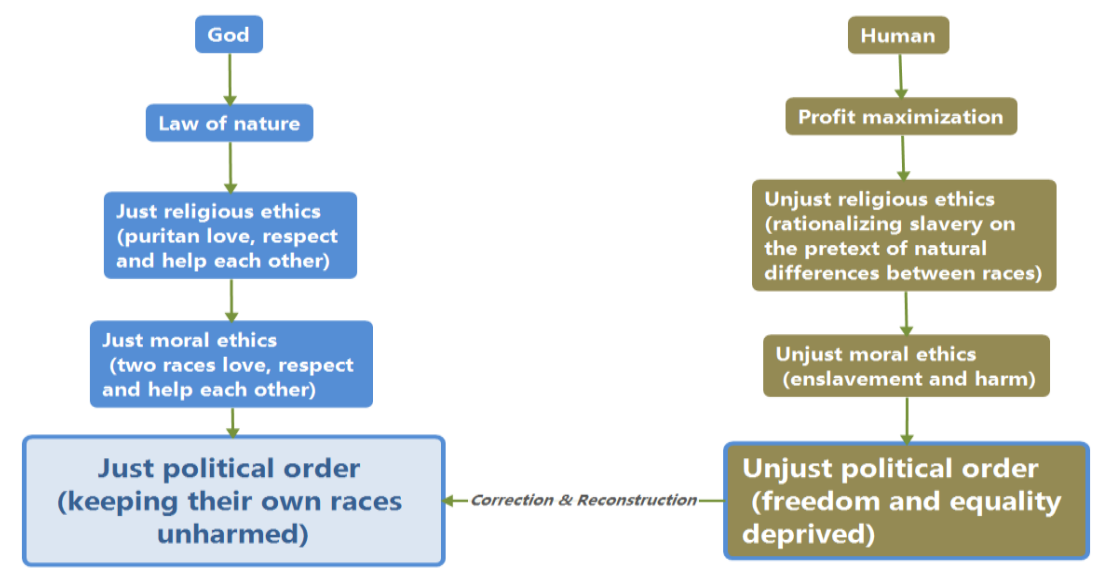

Figure 2. Evolution path of the early political view of African American

As shown in the figure, the evolution path of the early political view of African American can be understood as follows: Firstly, 1) the order of the world beyond God is the basis and reference of the order of the real world; 2) the law of nature, or law, as seen by the early blacks, were created by God; 3 ) religious ethics should be constructed in accordance with the logic of natural law, that is, in accordance with the law of God; 4) moral ethics in line with religious ethics is the moral and ethical order of justice; 5) the political order constructed according to the moral and ethical order of justice is the political order of justice.

Secondly, 1) God sets everyone equal before God; 2) that "everyone is equal before God" is natural law (law); 3) on the basis of equality in the presence of God, the ethical order of love, respect and help among Puritans was established; 4) the moral and ethical order is constructed according to the Puritan ethics, and the two races should respect and love each other and help each other; 5) the political order is constructed in accordance with morality and ethics, and both races should enjoy the right to keep their own races unharmed at the same time. In other words, God's will is religious ethics; Religious ethics is the basic model of establishing moral and ethical order of justice; Moral and ethical order is an important yardstick to construct a sound political order.

However, in the eyes of the early black American, racial slavery is a cancer in the American political system, which directly leads the righteous political order into the unjust political order. It is a manufactured thing produced to satisfy the accumulation of wealth; Driven by profit maximization, it even reinterprets doctrines, constructs unjust religious ethics, and rationalizes slavery on the pretext of natural differences between races. On this basis, enslavement and harm become the necessity of moral and ethical order. It deprives the black people of freedom and equal rights, and finally constructs an unjust political order. Thus it can be seen that in the minds of the early blacks, racial slavery does not conform to either religious ethics or the moral and ethical order of justice, and even against the law of nature and the will of God. Therefore, only by abolishing the racial slavery, can the imprisoned black American be free, and can the American politics be put on the road of real democracy. In short, under the influence of Puritan equality, American blacks start from spiritual equality, pursued equal rights and embarked on a road leading to freedom and liberation.

\section{The Cultivation of Early African American Political Thinkers in the Puritan Life}

From the perspective of the cultivation of political elites, Puritan life is the cradle of the growth of black political elites in America. In religious affairs, the African American political elite not only acquired the necessary skills such as speech and eloquence, political logic and expression. Moreover, it is easier to gain respect, honor and worship in the black community, thus becoming an important spokesman of the black community. To some extent, "if white political leaders in the United States are mostly lawyers, black political leaders in the United States are mostly priests" (Wang, 2006, p. 293). 
The relationship between puritanism and African American appears to have some kind of inevitable connection. The combination of the two is not only a derivative of social conflicts, but also an inevitable thing of historical development. In the face of social conflicts, religious creed became a script that was constantly being blotted out and revised, while God became a puppet that was arbitrarily controlled by some part of white people. However, God was innocent, and the biggest mistake was the selfish and greedy human nature, creating a pile of miserable howling and bleeding. By reinterpreting the doctrine and even changing the content of the doctrine, some part of white people christianized the black people to maintain the reasonable legitimacy of slavery and seek personal gains. To some extent, Christianity was instrumentalized and became an effective means for some white people to paralyze and control black people. Some blacks, however, were suspicious and intolerant of Christianity with its obvious racial chauvinism. Chen (2010) noted that "the white man's attempt to turn Christianity into a mere propaganda of obedience was resented and opposed by the slaves" (p. 162). However, the majority of black people's attitude towards Christianity was not completely negative or completely accepted, but transformed in the process of acceptance and turned into an ideological weapon that black people could use. So, the African American religion was born.

Obviously, Christianity in the context of social conflict was thoroughly instrumentalized. It was not only a tool for some white people to maintain racial slavery, but also a temporary home for black people to escape the harsh reality and find a way to survive. Rather than saying that whites christianized blacks in the context of racial conflict; rather, it was the black people themselves who were initiative to seize the life-saving straw to save themselves by focusing on the real situation.

Actually, active or passive, space and time are full of direct and indirect links; and, these intertwined veins of history, constitute a variety of historical inevitability. During that time, racist chauvinism was sweeping across the North America, and even Christianity was becoming infected by this "virus". It should be made clear, therefore, that the Christianization of black people by some white people was not a complete practice of equality before God; but only used Christianity to restrain the black's independence. Actually, the fundamental purpose was to tame the black into obedient slaves. Thus, to some extent, the historic participation of Christianity did not break the deadlock of racial discrimination thoroughly, but during the special history, was utilized by some part of white people to enrich the content of racial segregation in the field of religious affairs.

As a devout Christian, the first stop on the political journey of Frederick Douglass, a black American, began in church life. Douglas, who fled from the depths of slavery, fled first to New York, then to New Bedford, then to Massachusetts. Among them, his growth at New Bedford has been extremely rapid. He not only caught up to the African Methodist church, but also became a preacher and then a licensed minister. At the same time, Douglas became active in the abolitionist movement. Not only did he actively attend and participate in the meetings of the New Bedford abolitionists, but his admirable speeches at the meetings also earned him a certain degree of status and prestige. To some extent, it helped Douglas gradually with acquiring such important abilities as speech, inspiration, communication and management the daily affairs of the church by frequent contact with important figures in the church, listening to sermons and being active in the abolitionist movement as a member of the church. This laid a theoretical and practical foundation for him to thoroughly baptize the humble slave soul and grow into a real black political leader in the abolitionist movement.

Frederick Douglass was always passionate and enthusiastic about the black church, because it was the black religion that made him gain fame and status, and it was the black religion that transformed a "private property" once living at the bottom of society into a well-known abolitionist. Since Douglass's first political attempt began in the pulpit, his political theory was more closely related to religious beliefs. In general, Douglass's view of religious morality sought to tie closely together religious beliefs and political values through universal moral laws. With the background of black struggle, with the purpose of anti-discrimination and oppression, with the support of everyone being equal before God, and with the purpose of promoting the symbiosis and integration between black and white races, he mercilessly castigated the unjust deeds in realpolitik. Willing to participate in religious life, Frederick also deeply realized the severity of racial discrimination and segregation in religious life. In the daily Christian worship, although white people could bring their own black slaves to participate; however, black people could not sit with white people, but must be separated from them. Frederick Douglass once described a Christian baptism scene as this way:

The white members went forward to the altar by the bench full; and when it was evidence that all the whites had been served with the bread and wine, Brother Bonney...after a long pause, as if inquiring whether all the white members and been served, and full assuring himself on that important point, then raised his voice to an unnatural pitch, and looing to the corner where his black sheep seemed penned, beckoned with his hand, exclaiming, "Coming forward, colored friends!-come forward! You, too, have an interest in the blood of Christ. God is no respecter of persons. Come forward, and take this holy sacrament to your comfort!" The colored members-poor, slavish souls went-forward, as invited. I went out, and have never been in that 
church since, although I honestly went there with a view to joining that body. (Lampe, 1998, p. 37)

Douglas's attitude toward segregation based on racial discrimination was always clear: it was unacceptable for some part of white people to misunderstand the Christian doctrine, and it was also objectionable for some part of white people to maliciously create a hypocritical order. And, through biting satire and insightful speeches, he punctually debunked shameless charlatans of some whites, and laid bare the naked truth that had no cover. As Frederick Douglass leave it in his speech in New York State on July 5, 1852, he put the political facts straight. "I am not covered by this glorious day! Your parents left a rich heritage, including justice, freedom, prosperity, and independence, but they can only by you rather than me to share" (Foner, trans., 2010, p. 588). However, for the American black political elite whose childhood and youth were both shrouded in racial slavery under, discrimination and oppression not only didn't let his soul degenerate into slavery, instead, inspire his morale, prompted him to grow up to be an excellent black political elite. So, Christianity was of great significance in the formation of his political thought and the cultivation of his political ability. It can be said that religious affairs and religious life were the warm-up stage of his political career.

\section{The Formation of the Concept of Self-reliance of African American Cultivated by Puritan Ethical Spirit}

The basic codes of conduct of the Puritan ethic, such as diligence, frugality, cleanliness, and propriety, had a profound influence on the cultivation of the code of conduct and the formation of the self-reliance consciousness of the American black people.

The black American in history was a group of brave and strong people who suffered so much. At the height of the slave trade, blacks were regarded as a kind of "black gold" and sold in large quantities to the North American continent. Slave traders went to great lengths to obtain more of the flesh and blood of the "black gold". In addition to the brazen methods of abduction, deception, and the forcible abduction, trade with tribal leaders was also a common practice. When the deal was completed, the blacks were shipped back to the North American colonies. Because of the long and inhumane process of transportation, only a few blacks made it to the North America alive. According to some historical records, we know that the blacks who got on the ship were tied together in pairs, one close to the other. They huddled in a space of less than a cubic meter each, knees to their chins. Benjamin Brawley in A Short History of the American Negro described precisely the process of slave trade and the real life of slaves in the plantation. According to Brawley's descriptions, the food for black slaves was monotonous, drinking water was scarce, and blacks often suffered from mental breakdown and even mental disorders; what's worse, sometimes those blinded and suffered inflammations were cruelly thrown into the sea to fed to sharks (1929). The Negro, who was fortunate enough to be seen the sunshine of the North American continent; but, what awaited them was purgatory on earth.

As the private property of slaveholders, the blacks were just a tool that could talk at the disposal of the slaveholders, and then, the black slaves had to learn some kind of conduct code of the white society in order to survive. However, as black people flooded into the North American continent, black culture and white culture encountered the first ever strong impact. In the face of this aggressive expansion of the white civilization, the black became the prey upon the persecutor. During that time, in terms of the average level of education, most of the slaves who were produced from Africa were in a state of ignorance and superstition. And, for a long time, most of the blacks who entered the land of the North America as slaves were illiterate. Because in some parts of the North, it was illegal to teach black slaves to read; As a result, the vast majority of blacks had little chance of obtaining an education. Even if some of them were lucky enough to receive an education, they were only required to learn some kind of code of conduct in order to make blacks more obedient slaves. So, this kind of highly purposeful education is obviously a tool for some part of the white people to exert mental control over black people.

From the perspective of the category of slaves, the behavior habits of the black domestic slaves came closer to the Puritan ethical spirit, and their personal qualities were often higher than those of the field slaves of outdoor farming. This was because slave owners, in order to preserve the prestige of the family, would usually educate the black family slaves on the code of conduct. On the one hand, with the help of the indoctrination of this code of conduct, not only the service level of black slaves could be continuously improved in providing better service for their masters, but also it could continuously strengthen the black people's identification with slavery. On the other hand, if in front of the guests, the black slaves in the slave-owner's family were meek, behaved properly, dressed neatly, did things safely and honestly, it was easier for slave owners to gain stronger social identity and family prestige.

However, every coin consists of two sides. Since most of the white slaveholders almost believed in puritanism, the moral ethics and codes of conduct observed by the pious puritans in their daily life were undoubtedly the Puritan precepts. Then, the Puritan spirit was also unconsciously instilled into the minds of black people during the process of slave owners' extraordinary demands on black slaves. For the slaves, puritanism was used to restrain the moral and ethical norms of the believers, and then became the survival rules and living standards that the black slaves had to comply with. Perhaps the slaves who were suffering from harsh requirements did not quickly realize that under the 
constraint of Puritan moral ethics and code of conduct, as slaves, they were getting closer and closer to the thinking mode and behavior mode of the white middle class and were gradually walking on a road leading to freedom. After Frederick Douglass, Booker T. Washington, another black American political elite, was deeply influenced by the Puritan spirit in his youth. Especially, it indeed made a great influence on the formation and evolution of Washington's Tuskegee idea. To speak of Booker T. Washington, it was necessary to mention two persons, Mrs. Viola Ruffner and Mr. Samuel Armstrong.

In Mrs. Ruffner's house, Washington came to understand the importance of Puritan ethics of thrift and self-reliance. And, acquisition of decent behaviors laid the foundation for him to become an excellent student after entering Hampton school. Specifically, fifteen-year-old Washington, under the guarantee of his mother, worked in Mrs. Ruffner's house as a servant. She was the wife of General Lewis Ruffner and the owner of the coal mine. None of the children who had been servants in her family could satisfy her. Although Washington was very reluctant to be a servant to such a woman; but the job of a child servant did not seem so bad compared with that of a coal miner. In the end, "Mrs. Rufner hired him at six dollars per month and room and meals" (Spencer, Jr., 1955, p. 24). However, the process was not so smooth. Repetitive work finally made Washington unbearable and ran away. Nevertheless, when he first went out of his familiar place alone to face the cruelty of the outside world, Washington chose to return to Mrs. Ruffner's home. Mrs. Rufner was a pious Puritan who, while respecting the Puritan moral codes strictly on a daily basis, conveyed these ways of thinking and codes of conduct to young Washington. Washington (1901) wrote of her in his autobiography, "Mrs. Ruffner was a New England woman, with all the New England ideas about order, cleanliness and truth" (p. 27). Actually, experience living with Ruffner had a profound influence on the cultivation of Washington's excellent character. It was these Ruffner's Puritan ethical norms that prompted Washington to recognize that the gap between black people and white people and the self-improvement of black people was a crucial step in the process of national self-salvation.

Samuel Armstrong, headmaster of the Hampton school, was a more influential influence on Booker T. Washington than Mrs. Ruffner. After attending Hampton school, Washington was impressed when he first saw Armstrong. From that moment on, Washington found his first idol. In his account of his youth, Washington (1901) said of the great headmaster:

After I had been at the Hampton Institute a day or two I saw General Armstrong, the Principal, and he made the impression upon me of being the most perfect specimen of man, physically, mentally and spiritually, that I had ever seen; and I have never had occasion to change my first impression. (p. 37)

Armstrong was a case in representative of the white middle class, his theory was the bourgeois theory, and his mode of thinking and behavior had always been within the requirements of the bourgeoisie. Booker T. Washington was deeply influenced by his ideas and gradually formed the special idea of Tuskegee, which is, taking survivalism as the core content and blazing a new road of black rights movement, which was characterized by national self-reliance and political compromise. Besides, Washington's Tuskegee thought also including gradual improving the quality of the black community according to the Puritan spirit; relying on the power of the white's assistance, focusing on professional skills training, and vigorously developing the black economy; putting political rights on hold to avoid further aggravation of ethnic conflicts. Actually, the core of Tuskegee's thought lies in the self-awakening and self-rises of the black people.

Obviously, under the influence of Puritan spirit and moral and ethical norms, from the elites to the masses, the African American community gradually developed good behavior habits, which lay a practical foundation for the cultivation of civic spirit in the future. At the same time, along with the rise of a new generation of African American political elites, Puritan ethics and the spirit of capitalism provided spiritual food for the growth of new African American forces.

\section{Conclusion}

From what we have discussed above, we can see that as an extremely important school of thought, puritanism injects its main spirit and theory into the black American political thought imperceptibly. Undoubtedly, it is one of the important sources for the formation and evolution of the American black political culture. The ideas of freedom, equality, and autonomy in puritanism shaped the political character of the American nation, which advocated democracy, the rule of law and rights. At the same time, it also brought the light of enlightenment to the national liberation movement in the early stage and the social movement in the advanced stage.

Specifically, under the influence of puritanism, the African American political thought grew up gradually from the preliminary stage to more mature phase, especially in the cultivating of some early political concepts including equality and freedom; and, the political culture of African American had some basic characteristics, such as belief worship, moral supremacy, political view derived from religious ethics, and political order subject to moral and ethical order; besides, with living in the Puritan life, the early African American political thinkers were cultivated gradually including Fredric Douglass and Booker T. Washington. In addition, Puritan ethics such as diligence, frugality, diligence, 
cleanliness, and propriety had a great influence on the cultivation of the code of conduct of African American and the germination of the spirit of national self-reliance.

\section{References}

Almond, A. G., \& Powell, B. G. (1984). Comparative Politics Today. Boston, Little, Brown And Company.

Almond, A. G., \& Verba, S. (2008). The Citizen Culture: Political Attitudes and Democracy in Five Nations. Beijing: Oriental Press.

Booker, T. W. (1901). Booker T. Washington's Own Story of His Life and Work. New York: Fredonia Books.

Brawley, B. (1929). A Short History of the American Negro. New York: The Macmillan Company.

Chen, Z. J. (2010). Adaption and Antagonization: The Making of Black Culture under American Slavery. Beijing: China Social Sciences Press.

Foner, E. (2010). Give Me Liberty! An American History. Beijing: The Commercial Press.

Foner, P. S. (1975). History of Black Americans: From Africa to the Emergence of the Cotton Kingdom. New York: Greenwood Press.

Kahn, P. W. (2015). Put Liberalism in Its Place. Beijing: China University of Politic Science and Law Press.

Lampe, P. G. (1998). Frederick Douglass—Freedom's Voice, 1818-1845. Michigan: Michigan State University Press.

Litwack, L., \& Meier, A. (1923). Black Leader of the Nineteenth Century. Urbana and Chicago: University of Illinois Press.

Meltzer, M. (1965). In Their Own Words: A History of the American Negro 1865-1916. New York: Thomas Y. Crowell Company.

Miller, D., \& Bogdanor, V. (1992). The Blackwell Encyclopedia of Political Science. Beijing: China University of Politic Science and Law Press.

Nankai University, Department of American history. (1977). A Brief History of the African American Movement. Beijing: People's Publishing House.

Parrington, V. L. (2002). Main Currents in American Thought. Changchun: Jilin People's Publishing House.

Qian, M. S. (2006). The History of American Liberalism. Beijing: SDX Joint Publishing Company.

Tocqueville. (2011). Democracy in America. Beijing: The Commercial Press.

Wang, E. M. (2006). African American Leaders and Their Political Thoughts. Shanghai: Shanghai Foreign Language Education Press.

Zinn, H. (1980). A People's History of the United States. New York: Harper \& Row. Publishers.

\section{Copyrights}

Copyright for this article is retained by the author(s), with first publication rights granted to the journal.

This is an open-access article distributed under the terms and conditions of the Creative Commons Attribution license which permits unrestricted use, distribution, and reproduction in any medium, provided the original work is properly cited. 